\title{
Avulsion Fracture of the Anterior Iliac Crest after Bone Graft Harvest: Case Report and Review of Techniques, Risk Factors and Treatment
}

\author{
Kemik Greft Alınmasın Takiben Anterior Iliak Kıyı Kopma Kırığı: \\ Olgu Sunumu ve Tekniklerin, Risk Faktörlerinin ve Tedavinin Gözden \\ Geçirilmesi
}

\author{
Aysegul OZDEMIR OVALIOGLU ${ }^{1}$, Cumhur KILINCER ${ }^{2}$, Talat Cem OVALIOGLU ${ }^{3}$, Osman SIMSEK ${ }^{2}$ \\ ${ }^{1}$ Basaksebir State Hospital, Department of Neurosurgery, Istanbul, Turkey \\ ${ }^{2}$ Trakya University, Faculty of Medicine, Department of Neurosurgery, Edirne, Turkey \\ ${ }^{3}$ Vakif Gureba Research and Training Hospital, Department of Neurosurgery, Istanbul, Turkey
}

Correspondence address: Aysegul OZDEMIR OVALIOGLU / E-mail: draysegulozdemir@yahoo.com

\begin{abstract}
The anterior iliac crest is the harvest site preferred by many surgeons because of the quantity and quality of bone obtainable and the simplicity of harvesting techniques. Avulsion fracture of the iliac crest following bone grafting is an extremely rare occurrence. We present a case report of avulsion fracture of the anterior iliac crest following bone graft harvesting for anterior cervical fusion in a 63-year-old man. Non-operative treatment was the method of our treatment in the patient. By means of the presented case, iliac crest bone grafting techniques, risk factors of avulsion fracture, and treatment options were reviewed.
\end{abstract}

KEYWORDS: Bone transplantation, Cervical vertebrae, lliac crest, Postoperative complications, Spinal fusion

öz

Anterior iliak kıyı, nitelik ve nicelik olarak iyi bir kemik ve kolay alınabilir olması nedeniyle greft yeri olarak çoğu cerrah tarafından tercih edilmektedir. Spinal füzyon icin kemik alınmasını takiben iliak kıyı kırığı geliş̧mesi oldukça nadir gelişen bir durumdur. Anterior servikal füzyon için kemik greft alınmasını takiben anterior iliak kıyı kopma kııı̆ı gelişen 63 yaşında bir erkek hasta sunulmuştur. Hastadaki tedavi metodumuz ameliyat dışı tedavi oldu. Sunulan olgu aracılığıyla iliak kıyıdan greft alma teknikleri, kırık için risk faktörleri ve tedavi seçenekleri gözden geçirildi.

ANAHTAR SÖZCÜKLER: Kemik nakli, Servikal omur, İliak kıyı, Ameliyat sonrası komplikasyonlar, Spinal füzyon

\section{INTRODUCTION}

The iliac crest is a common donor site for cancellous and cortical bone grafts because it provides the highest concentration of osteocompetent cells and available volume. Bicortical or tricortical anterior iliac crest bone grafts are used for anterior arthrodesis after the cervical corpectomy, as the patient is in a supine position and stronger bone is available anteriorly $(8,14,18,22)$. This procedure is not problem-free. Chronic pain, neurological or vascular injury, infection, hematoma, bowel herniation, cosmetic defects, and fractures at the iliac crest are some of the reported donor site complications $(6,7,10,18,20)$. Avulsion fracture of the anterior iliac crest after bone grafting is a very rare complication. We report such a case with a review of anatomical features, technical details, and risk factors that are involved in the fracture of the iliac crest after bone grafting to prevent this complication.

\section{CASE REPORT}

A 63-year-old man was admitted with complaints of pain, weakness, and numbness at his left arm of 6 months' duration. Neurological examination revealed muscle weakness (4/5) of the distal muscle groups of the left arm. Cervical magnetic resonance images revealed bilateral foraminal stenosis and narrowing of the anterior subarachnoid space resulted by the degenerative changes at C4-5, C5-6 and C6-7 interspaces. The patient underwent $\mathrm{C} 5$ and $\mathrm{C} 6$ corpectomy followed by strut grafting using autologous tricortical bone graft harvested from the right anterior iliac crest, and stabilization with anterior plating. The patient's postoperative course was uneventful, and his symptoms were improved rapidly. He was discharged on the third postoperative day. 
Three weeks after the surgery, he was readmitted due to a sudden pain and a palpable lump on the right inguinal region after forceful physical activity. On physical examination, there was a mobile subcutaneous mass lesion about $5 \mathrm{~cm}$ in diameter located $5 \mathrm{~cm}$ caudal to the incision of the bone graft harvest. X-rays revealed the avulsion fracture of the anterior superior iliac spine at the right side (Figure 1). His pain gradually relieved in two weeks by symptomatic treatment with analgesics and activity restriction, and there was no complaint at the one year follow-up examination.

\section{DISCUSSION}

The iliac crest is commonly used as autologous bone source in spinal fusion procedures. Autologous bone graft is the gold standard as a fusion material because it has all the three properties of an ideal fusion material: osteoconduction, osteoinduction and osteogenesis. However, complications of bone graft harvesting procedures are not uncommon. Wound pain, infection, hematoma, hypersensitivity, superficial infections, seromas, meralgia parestetica, subluxation of the hip after extensive removal of the iliac crest, donor defect herniation, vascular injuries, nerve injuries, and iliac wing fractures are reported at a rate of $3.4 \%$ to $8.6 \%(2,5,29)$. The incidence of chronic donor site pain was reported to range from $6 \%$ to $39 \%$ in a subgroup of patients who underwent bone grafting as part of a spinal reconstructive procedure $(5,24)$.

Autogenous iliac crest bone grafting results in minimal morbidity if regional anatomy is respected and careful technique is employed. However, the downward pull of the attachments of the sartorius muscle and tensor fascia latae muscle on the anterior superior iliac spine may cause late stress fracture after anterior iliac crest harvesting. In fact, avulsion fracture of the anterior iliac crest after bone harvesting has rarely been reported in the literature $(2,11,13,14,15,21,23)$. Older age, osteoporosis and co-morbidities are significant risk factors for fracture of the iliac crest after grafting $(1,11,14)$. When removing large quantities of bone from the ilium, the base bearing the anterior iliac spine must be wide enough to reduce the risk of stress fracture by the downward pull of sartorius muscle. The strength of remaining iliac crest after graft removal was biomechanically studied by Hue et al. on human cadavers (15). The removal of bone $30 \mathrm{~mm}$ posterior to anterior superior iliac spine preserves 2.4 times more strength to the iliac crest compared with harvesting bone graft $15 \mathrm{~mm}$ posterior to the anterior superior iliac spine. Thus, the authors recommended that bone should be removed at least $30 \mathrm{~mm}$ from the anterior superior iliac spine. A morphological study of the anterior iliac crest regarding the optimal location of bone harvesting was conducted by Ebraheim et al. (9). The authors concluded that an oblique anteriorly angled bony cut would leave a narrow bone at the base, and predispose the anterior superior iliac spine to fracture. The mean thickness of the ilium measured at $3 \mathrm{~cm}$ posterior to the anterior superior iliac spine and at the iliac tubercle were 11.7 and $16.9 \mathrm{~mm}$. The region around the iliac tubercle is most suitable for harvesting bone

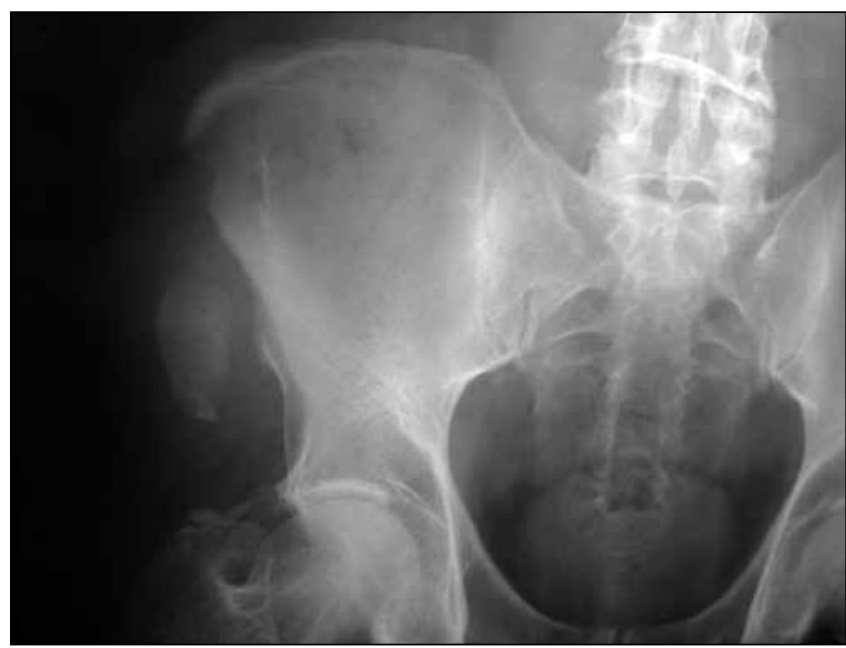

Figure 1: Avulsion fracture of the anterior iliac crest after bone graft harvest.

grafts. Ebraheim et al. (9) suggest that harvesting a bicortical bone block at the medial-superior cortex in the region of the iliac tubercle is safer than harvesting a tricortical graft. The subcrestal window method of bicortical grafting also is a suitable option in which iliac crest is preserved. Behairy and Al Sebai (3) used subcrestal window technique in 20 cases and concluded that this technique was straightforward and cost effective. It also leaves the iliac crest structurally stronger. Other than the place of harvesting, the tool used for bone removal is important. Jones et al (16) concluded that an osteotome-harvested graft had an increased incidence of propagation of fracture compared with saw-harvested bone grafts on fresh frozen cadavers. Thus, they suggested that the saw was a more desirable tool for harvesting grafts. It should be noted that, in the presented case, we had harvested a tricortical bone block at just posterior to anterior iliac spine, and using an osteotome. All three factors, namely place (close to the spine), shape (tricortical) and the tool used (osteotome), increase the risk of stress fracture at the anterior iliac crest (Table I, Table II).

The treatment of iliac crest fracture is usually non-operative with short period of rest followed by assisted ambulation and usage of analgesics until fracture healed $(11,14)$. Occasionally, fractures of the iliac crest necessitate additional surgical treatment. The most frequent complications in conservatively treated patients are exostosis formation, non-union and persistent pain. Surgical management should be considered if the fracture is widely displaced or there are no signs of union despite long duration of rest. Displacement of the fragment more than $3 \mathrm{~cm}$ inferolaterally, non-union and the situations that need short period of rest (eg. athletes, football players, comorbidities) are indications for open reduction and internal fixation for the avulsion fractures of the iliac crest. Rarely, fibrous union or persistent pain may be seen depending on the degree of displacement. Excision of the fragment may be useful in these cases. Duration of immobilization period and 
Table I: Table Showing the Technical Factors Affecting the Risk of Iliac Crest Fractures after Graft Harvesting

\begin{tabular}{|c|c|c|}
\hline Factors & Decrease the fracture risk & Increase the fracture risk \\
\hline Place of harvesting & Far to the AISI & Close to the AISI \\
\hline Shape of bone & Bicortical graft & Tricortical graft \\
\hline Tool used for harvesting & Saw & Osteotome
\end{tabular}

AISI: Anterior Superior lliac Spine

Table II: Table Showing the Hints to Avoid Iliac Crest Fractures after Graft Harvesting

1. Wide acquaintance with regional anatomy and harvesting techniques

2. Awareness of personal risk factors; older age, osteoporosis and co-morbidities

3. Avoiding of harvesting large quantities of bone from the ileum

4. Most suitable region for harvesting bone graft is around the iliac tubercle

5. Prevention of forceful activity after graft harvesting

return to activities is shorter in the surgically treated patients (27). Return to full activity in the avulsion fracture of the iliac crest is complete, with no restrictions or long term sequelae with both conservative and open treatments. We preferred not to intervene as the symptoms resolved with conservative care.

Most of the iliac crest fractures reported in the literature occurred in the first week after the harvesting procedure. The current case had the fracture three weeks after the procedure. He probably had a silent fissure line at the iliac crest, weakening the base of the anterior superior iliac spine. A forceful activity causing contraction of the sartorius muscle should cause avulsion of the weakened bone part. Pain of donor site wound may mask the pain of underlying fracture or a fissure line at the iliac crest. Thus, a postoperative x-ray of the pelvis may be useful at those patients with severe pain at the donor site. Detection of a fissure line requires restriction of physical activities, allowing the fissure line to heal, and to prevent avulsion. It should be remembered that some patients who underwent cervical spine surgery might have some neurological deficits and absence of pain perception at the fracture site.

\section{CONCLUSION}

Although harvesting bone graft from the iliac crest appears to be a simple procedure, it may result in numerous complications. Avulsion fracture of the iliac crest after splitthickness bone grafting is an uncommon complication. Knowledge about the regional anatomy, proper surgical techniques and identification of the risk factors for fracture of the iliac crest after bone grafting is necessary to minimize this complication. The surgeon should be aware of the risk of avulsion fracture of the iliac crest in patients suffering from donor site pain after bone grafting. Treatment of an iliac crest fracture is almost always conservative, a period of bed rest followed by progressive ambulation.

\section{REFERENCES}

1. Al-Sayyad MJ, Abdulmajeed TM: Fracture of the anterior iliac crest following autogenous bone grafting. Saudi Med J 27(2):254-258, 2006

2. Arrington ED, Smith WJ, Chambers HG, Bucknell AL, Davino NA: Complications of iliac crest bone graft harvesting. Clin Orthop Relat Res 329:300-309, 1996

3. Behairy YM, Al-Sebai W: A modified technique for harvesting full-thickness iliac crest bone graft. Spine 26:695-697, 2001

4. Chase SW, Herndon $\mathrm{CH}$ : The fate of autogenous and homogenous bone grafts: A historical review. J Bone Joint Surg 37A:809-841, 1955

5. Cockin J: Autologous bone grafting-complications at the donor site. J Bone Joint Surg 53B:153, 1971

6. Coventry MB, Tapper EM: Pelvic instability: a consequence of removing iliac bone for grafting. J Bone Joint Surg 54:83-101, 1972

7. Cowley SP, Anderson LD: Hernias through donor sites for iliacbone grafts. J Bone Joint Surg 65A:1023-1025, 1983

8. De Palma AF, Rothman RH, Lewinnek GE, Canale ST: Anterior interbody fusion for severe cervical disc degeneration. Surg Gynecol Obstet 134:755-758, 1972

9. Ebraheim NA, Yang H, Lu J, Biyani A, Yeasting RA: Anterior iliac crest bone graft. Anatomic considerations. Spine 22:847, 1997

10. Flint M: Chip bone grafting of the mandible. Br J Plast Surg 17:184-188, 1964

11. Friend KD, Koval KJ, Mirovsky Y, Remer SS, Bloom N, Neuwirth MG: Fracture of the iliac crest following bone grafting: A case report and literature review. Bull Hosp Jt Dis 54:49-51, 1995

12. Goldberg VM, Stevenson S: Natural history of autografts and allografts. Clin Orthop 225:7-16, 1987

13. Guha SC, Poole MD: Stress fracture of the iliac bone with subfascial femoral neuropathy: Unusual complications at a bone graft donor site: Case report. Br J Plast Surg 36:305-306, 1983 
14. Hu RW, Bohlman $\mathrm{HH}$ : Fracture at the iliac bone graft harvest site after fusion of the spine. Clin Orthop Relat Res 309:208, 1994

15. Hu R, Hearn T, Yang J: Bone graft harvest site as a determinant of iliac crest strength. Clin Orthop Rel Res 310:252, 1995

16. Jones AA, Dougherty PJ, Sharkey NA, Benson DR: lliac crest bone graft. Osteotome versus saw. Spine 18:2048, 1993

17. Kuhn DA, Moreland MS: Complications following iliac crest bone grafting. Clin Orthop Rel Res 209:224, 1986

18. Kurz LG, Garfin SR, Booth RE: Harvesting autogenous iliac bone grafts. A review of complications and techniques. Spine 14:1324-1331, 1989

19. Lichtblau S: Dislocation of the sacroiliac joint: A complication of bone grafting. J Bone Joint Surg 44A:193-198, 1962

20. Reid RL: Hernia through an iliac bone graft donor site. J Bone Joint Surg Am 50:757-760, 1968

21. Rush LV, Rush HL: Avulsion of the anterior superior spine of the ilium. J Bone Joint Surg 21:206-207, 1939
22. Smith GW, Robinson RA: The treatment of certain cervicalspine disorders by anterior removal of the intervertebral disc and interbody fusion. J Bone Joint Surg 40A:607-624, 1958

23. Stoll P, Schilli W: Long-term follow-up of donor and recipient sites after autologous bone grafts for reconstruction of the facial skeleton. J Oral Surg 39:676-677, 1981

24. Summers BN, Eisenstein SM: Donor site pain from the ilium: A complication of lumbar spine fusion. J Bone Joint Surg $\mathrm{Br}$ 71:677-680, 1989

25. Urist MR: Practical Applications of Bone Research on Bone Graft Physiology. St Louis: CV Mosby, 1976

26. Valdés M, Molins J, Acebes O: Avulsion fracture of the iliac crest in a football player. Scand J Med Sci Sports 10:178, 2000

27. Veselko M, Smrkolj V: Avulsion of the anterior-superior iliac spine in athletes: Case reports. J Trauma 36:444-446, 1994

28. Weikel AM, Habal MB: Meralgia paresthetica: A complication of iliac bone procurement. Plast Reconstr Surg 60(4):572-574, 1977

29. Younger EM, Chapman MW: Morbidity at bone graft donor sites. J Orthop Trauma 3:192- 195, 1989 